\title{
Multiculturalism in Indian English Literature
}

\author{
V. Beulah Rani*, M.A., \\ Lecturer in English, Hindu College, Guntur
}

*Corresponding Author: V. Beulah Rani, Lecturer in English, Hindu College, Guntur

\begin{abstract}
India has several sophisticated literary languages. The languages have long standing literary traditions. English is assumed as the main literary language as it has been given the status of "official language" by Indian Constitution. Multiculturalism in Indian literature is different from other post-colonial literatures in English. The main objective of this paper is to probe the role of Multiculturalism in Indian English Literature.

An Indian is inevitably bicultural and lives within a bilingual and multilingual cultural idiom. He is born with a skill to switch his cultural-code according to the needs of his social situation. He even lives within an organic and native social context. The traditional terms used in Indian languages that institutionalised these diverse pulls were "Marga" and "Desi".

In India it is not possible to have a truly autonomous Indian English style. Metophorically speaking the body of modern Indian culture is draped in ancient shoes, a medieval gown and a modern hat. Multiculturalism should bring a new strength to a literature.
\end{abstract}

Keywords: Multiculturalism, Intimate Enemy, Elite Culture, Middle Class Culture, Marga, Desi, Tripartite Relationship, Four Predictable Styles, Parampara, Openness, Electrism

\section{INTRODUCTION}

Role of English in Indian literature is a curious cultural phenomenon, but English is not an Indian language. It is the language of England, Ireland, Australia, Canada, and the USA. India has several sophisticated literary languages. The languages have long -standing literary traditions. Many students of other Countries think that India has no literature other than that written in English. It is assumed English is the main literary language in India because it has been given the status of "official language" by the Indian Constitution. In reality, Indian English literature is the newest developed branch of Indian literature. For an Indian writing in English involves a conflict between the mother tongue and English, this other tongue which has been our intimate enemy during the last two centuries.

English was introduced as a medium of instruction into the Indian education system in 1835 by Lord Macaulay. The British rules of of India saw it as an intellectual tool to be used to civilize the natives. When English literature was included in school and University Courses, India already had a long and rich tradition of literature at the juncture of this encounter was being written in more than a dozen living languages, but since in English literature was produced in the country of the rulers, and was praised by them, it immediately acquired a high cultural status in India. Indian culture has been eclectic in the extreme. It has had a long tradition of receiving foreign influences. The English term culture is not sufficiently large to cover the semantic scope of the cultural situation in India. The term pervasive traits of a class or a section in a given society. Terms like Elite culture or Middle - class culture are efficient and adequate to describe the true cultural character groups.

Speaking of multicultural context with reference to Indian literature is different in some important ways from speaking of it in the context of other post-colonial literatures in English. In India there has been such a complex inter relationship between various social, linguistic, racial and religious cultures, and these distinguishable sub cultures are so numerous, that it is virtually impossible to fit them in a common formula of sociological linguistic or ethnic cultural structure. We should not compare simple multicultural contexts and complex multicultural contexts. It is rather to compare complex and confusingly complicated contexts. Such complications are inevitable in a society that speaks nearly 80 languages, writes it's literature in nearly 20 different languages, has a history of large-scale social 
migrations for every 3000 years. Indian literature in English is India's youngest literary tradition with a very short history of about 100 years. Multiculturalism on the other hand is the oldest and the most durable feature of the Indian way of life.

An Indian, however is inevitably bicultural and lives within a bilingual or a multilingual cultural idiom. He is born with a skill to switch his cultural-code according to the needs of his social situation. And even he lives within an organic and native social context, with many mainstream cultural traditions and several sub stream cultural currents. The traditional terms used in Indian languages that institutionalised these diverse pulls were Marga and Desi. The Marga being the cultures pervading the entire subcontinent horizontally and the Desi, being the vertical, local, fast-changing features of one's cultural identity. Traditionally, the social mobility brought about by economic upheavals, religious convensions and linguistic affinity. Perhaps it is possible to perceive this complicated social fragmentation and formation in terms of a tripartite relationship in the marga traditions the alien traditions and the desi traditions. The alien traditions in India imitated in part the Marga traditions and in part Desi traditions. These were at once stylised, formalised and given a dominating place in Indian culture. And at the same time, used pragmatically and in close correspondence with life as it was like the traditions of the desi types. English literature produced in India has acquired this double identity, at once stylised and pragmatic.

Therefore there are some problems for Indian literature in English which are unique in the entire gamut of commonwealth writings. The first is a split in its personality. The mainstream being considered inherently superior. By imitating both, the alien traditions in India develop a compulsion to be a pan-Indian as well as true to the local nuances and the colour. The styles of Indian literature in English show clear signs of this compulsion. For example, even after writing for more than half a century both R.K. Narayan and Mulk Raj Anand still have to keep translating their regional concepts and terms into neutral English. The same problem is faced by a dialect writer in England or by a South American writer. The compulsion to write two-tonal, text-neutral and coloured does not come merely from the fact of the Indian writer's being bilingual/ bicultural. V.S. Naipaul and Salman Rushdie, the non-typical Indian writers are bicultural too, but they have evolved a complete stlye after escaping the cultural split that a typical Indian writer has to suffer. It is because of this split that excessive stress has to be given on irony and humour, myth and rhetoric and verbal features of characters.

The English language in India is treated as a superior language in comparision with Indian languages. The Indian writer likes to claim it as his own 'Indian' language, at the same time he writes for the readership belonging to that social class. With this split, the Indian English style can barely become a discourse. The other problem of a serious nature by conflicting cultural demands on English literature in India is related to growth. The Indian nation has accepted the English language as one of its two national languages, the other being Hindi. But whereas Hindi is a regional language and has a specific geographical base but English does not. The result is that it is used, on the one hand, as a language of status and on the other as a static language. Because of an international language it is called as status language and not being an Indian language it is more learnt than spoken in India, so it is a static language. It enjoys as an enormously resourceful language that it has been elsewhere. The inevitable consequences of this attitude, in order to keep in with the international status of the language most writers assume a learned ironic tone at the same time; to rid it of its stasis, burden it with excessive local colour. A good example of these attitudes is" Nissim Eziekel's poems ", in which ambivalence pervades the reproduction of somewhat comical but truly Indian use of English. The other example is Aurobindo's epic "Savitri" written in Miltonic diction replete with references to the stylized filklore of the ancient past. Thus, the English language in India is legitimated as a national language but treated only as an international language and used for conveying the local colour. It carries the burden of the tripartite relation between the marga, the alien, and the desi, like other cultural institutions in India.

The tripartite cultural relationship can be seen in a large number of writers particularly those given to self-examination. For example R. Partha Sarathy, whose poem. "Rough Passage" is an eloquent of this relationship. The poem is divided into three sections, Exile, Trail and Homecoming. The first section shows him in an alien British setting stunned with the discovery of being an Indian. The idiom of the poem and the quality of emotion in this section one comparable to the western standard of alienation. The second section is about poet's journey, and his relationships, the final sections is about 
his personal growth, through philosophic disillusionments. The poet brings together the western, the Marga and the Desi expectations to bear upon the subject. The other major poems in Indian English literature- Sri Aurobindo's "Savitri" and Jayanta Mahapatra's "Relationship- from this perspective". Thus, English as a medium of creative writing in India spreads the writers canvas too wide but dilutes his colours rather too much. R.K.Narayan's "The painter of signs" or "The Talkative man" seem to portray the prototype of the Indian writing in English.

The entire history of Indian English literature of various patterns of conflict and collaboration between the western, the Marga and the Desi cultural traditions, such a fate seems to have been inscribed in the being of Indian English literature from the moment of its birth. Briefly refering to the context of its birth Indian writers had acquired the skill of writing in alien languages much before the English language arrived in India. Indian writers wrote using Arabic or Percian languages of alien extraction. Amir Khosrau of $13^{\text {th }}$ century, and the sanskrit poet Jagannath pandit were bilingual, to mention just two of the numerous avilable examples, who wrote in languages other than their own. When English literature was introduced into Indian educational system there was no senseof outrage in contemporary Indian intellectuals. Thinkers like Raja Ram Mohan Roy, some Britsh ideologists inspired by Sir William Jones demanded education through the established medium of Arabic and Sanskrit. The debate now known as the Anglicist and the orientalist debate. But there was a conflict between the western and the Marga cultures. There were already well established literary traditions in these languages such as Gujarathi, Tamil, nad Marathi. These were the Desi traditions. The final outcome of the debate was that the British administration in India decided to incorporate all the three components in the education system. Even today the official language policy of the Indian Government is known as the three language policy. Because of the consistency of this policy from 1835 to this day, Indian writings in English remains confined to all three cultural strands, and works simultanously within them all.

The multicultural context of Indian literature in English produces the following four predictable styles of writing:

- Style in which internationalism and nationalism meet and collaborate, where the alien cultural features work together with the marga cultural feature. In fiction the ideal example is Raja Rao, who combines an International sort of existentialism with national sort of sentimentality.

- Style in which nationalism or the Marga cultural features merge with the local or the discultural features. In fiction, a good example is Prathap Sarma's novel on Punjab, "The day of the Turban ".

- Styles in which the International cultural features conflict with the national or the marga features were irony and sentimentality constantly thwart each other. Mulk Raj Anand's usual style belongs to this type.

- Style in which the national and the regional, the marga and the desi cultural features are at cross purposes. R.K.Narayan at times seems to be facing this problem.

In poetry, A.K.Ramanujan, Jayantha Mahapatra, Sri Aurobindo and R. Partha Sarathy exemplify the four types respectively. Following this line of argument, one could maintain that in India it is not possible to have a truly autonomous Indian English style. The style varieties of Indian English literature are linked to the multicultural context of it. The tension between the three cultural streams in contemporary India could have become vigorously creative. The alien culture embodied in the English language is of recent origin and has a short history of a century or so. The desi culture emerged in India around the beginning of $20^{\text {th }}$ century and have acquired and retained the sociological dents of all those centuries. The marga traditions emerged even earlier, and many are as old as Indian civilisation itself. Thus the three cultures originate in an agrarian, a feudal and an industrialised society, respectively. Metaphorically speaking the body of modern Indian culture is draped in ancient shoes, a medieval gown and a modern hat. The problem is further complicated because the Indian sesibility invests disproportionate value in what is ancient even when it is unusable, and also in what is young even when it is not fully mature. Thus sanskrit and the culture based in it, as well as English and the culture surrounding it are treated with reverence. It is in fact the Indian sense of tradition as Parampara that is at play behind such attitudes to language and culture. Indian history has as similaited languages well - preserved in India's cultural memory. And Indians learn foreigner's 
language very quickly. But these learned languages are always maintained as essentially foreign and imperfectly assimilated. The literature produced in India is traditionalised at a slow pace.

Indian literature in English also has the context of colonialism in its origin. Colonialism had two major consequences for Indian culture, one was an upsurge of a revivalist tendency, the other was the growth of a desire to imitate the British. The revavalistic tendency fanned by the Indological admiration for the ancient Indian culture created excessive respect for the remote Indian past. The desire to imitate it created undue sense of awe for English language. Socialogists describe these two tedencies with the terms 'sanskritisation' and 'westernisation'. These two trends have been institutionalised in modern Indian culture and literature. The implications of such a process for a growing literary tradition are the serious aberrations, are created in its self-awareness, and the growth of its own tradition becomes tortuous.

\section{CONCLUSION}

Literature becomes a great literature when it develops from a language that is rooted in the soil that grows organically from people's experiences piled together for generations. The English language was grafted onto India's linguistic banyan tree. It has been a successful grafting only to a limited extent, for the language has still not taken firm root in the soil. As a result the literature produced in it has to operate within a severely limited social space. Hence, Multiculturalism has not been a sufficiently fruitful context for its survival and growth.

Having outlined the specific cultural pressures on Indian English literature, it is necessary however, to state that the role that it can play lies within the marga tradition, as a national literature of India rather than as a regional literature of any desi tradition. Whether we like it or not the fact remains that at the moment it is the only national literature in India. And for depicting the marga side of modern Indian life it is the only vehicle. Its growth will depend on its realisation of this role, on its quickness to rid itself of its multicultural context.

\section{REFERENCES}

[1] M. Rajagopalachary, K. DamodarRao, Multiculturalism in Indian tradition and literature.

[2] Lakshmi, Vijay “ Of Immigrant's writing “ Dislocation and Multiculturalisms, Ed. Jasbir Jain, ( New Delhi : Rawat Publication, 2004) P:52

[3] Ashok Bhaskar "Multiculturalism in Indian fiction in English".

[4] Luniano, W.(1996), “ Like being Mugged by a Metaphor : Multiculturalism and state Narratives”. In Mapping Multicularalism, eds. A.F. Gortdon and C. New field. Minneapolis: University of Minnesota Press.

Citation: V. Beulah Rani. "Multiculturalism in Indian English Literature" International Journal on Studies in English Language and Literature (IJSELL), vol 7, no. 3, 2019, pp. 26-29. doi: http://dx.doi.org/10.20431/ 2347-3134.0703004.

Copyright: (C) 2019 Authors. This is an open-access article distributed under the terms of the Creative Commons Attribution License, which permits unrestricted use, distribution, and reproduction in any medium, provided the original author and source are credited. 